\title{
The effect of charantin on expression of Ngn3 gene in streptozotocin- induced diabetic rats
}

\author{
Abolfazl Nasirzadeh Vanhari ${ }^{1}$, Hossein Sazgar ${ }^{2}$ \\ ${ }^{1} \mathrm{MSc}$ in Biology and Biochemistry, Department of Biology, Faculty of Basic Sciences, Shahrekord Branch, Islamic \\ Azad University, Shahrekord, Iran \\ ${ }^{2}$ Assistant Professor of Physiology, Department of Biology, Faculty of Basic Sciences, Shahrekord Branch, Islamic \\ Azad University, Shahrekord, Iran
}

\begin{abstract}
Background: Positive effects of medicinal herbs on diabetes have been demonstrated in previous studies. The aim of the present study was to evaluate the effect of charantin on the treatment of diabetes and increase the expression of the Ngn3 gene in diabetes, which is a key gene for transcription of the pancreas.

Materials and methods: In this experimental study, 42 adult male Wistar rats were randomly divided into 7 healthy control groups, diabetic control, control group, 150 control, and three groups receiving effective doses of charantin (50-100-200 mg/ Per kilogram). All groups except diabetic control group and control group with streptozotocin chemical injected intraperitoneally. Afterwards, they received a cartilage by gavage for four weeks (three times a week).

Results: The lowest expression was observed in the diabetic group. Among those who received different doses of charantine, the highest expression was among group with dose of $100 \mathrm{mg} / \mathrm{kg}$, and the lowest expression in $50 / \mathrm{kg}$ group.

Conclusion: It can be concluded that increased expression of the Ngn3 gene was not dose-dependent. After the development of diabetes, the patient's severity declined sharply, and after the use of the charantin and metformin drug, this reduction was somewhat offset.
\end{abstract}

Keywords: Diabetes, Streptozotocin, Charantin, Ngn3 gene.

Cited as: Nasirzadeh Vanhari A, Sazgar H. The effect of quarantine on expression of Ngn3 gene in streptozotocin-induced diabetic rats (STZ). Medical Science Journal of Islamic Azad University, Tehran Medical Branch 2019; 29(4): 303-312.

Correspondence to: Hossein Sazgar

Tel: +989177121993

E-mail: hoseinsazgar@yahoo.com

ORCID ID: 0000-0001-9769-8932

Received: 20 May 2018; Accepted: 3 Sep 2018 
مجله علوم يزشكى دانشَاه آزاد اسلامى

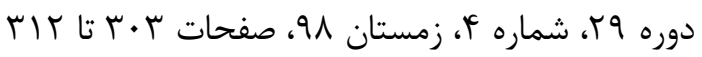

$\overline{\text { Original }}$

Article

\section{تاثير جارانتين بر بيان زن Ngn3 در رتهاى ديابتى شده با استر يتوزوتوسين}

\section{ابوالفضل نصير زاده ونهرى'، حسين سازگًارَ}

'دانشجوى كارشناسى ارشد زيست شناسى-بيوشيمى، كروه زيستشناسى، دانشكده علوم پايه، واحد شهركرد، دانشكاه آزاد اسلامى، شهركرد، ايران

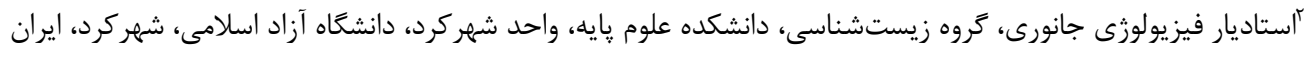
جـكيده

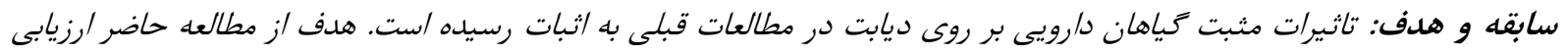

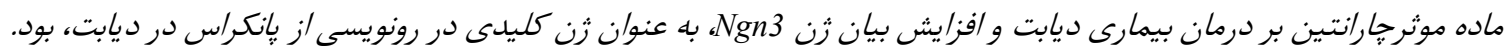

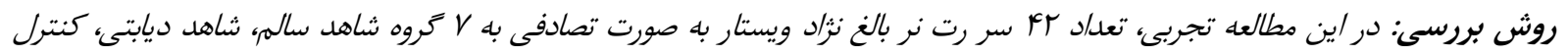

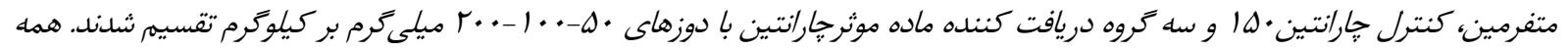

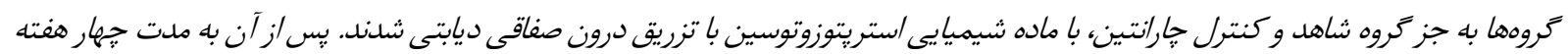

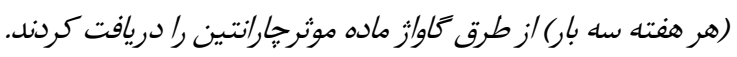

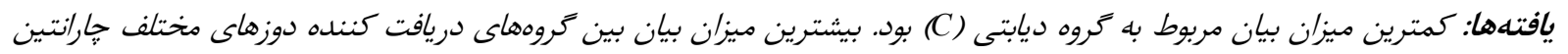

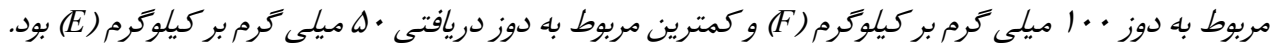

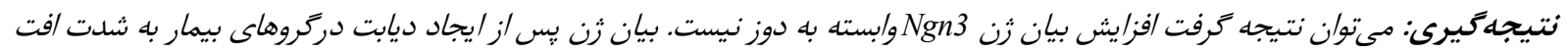

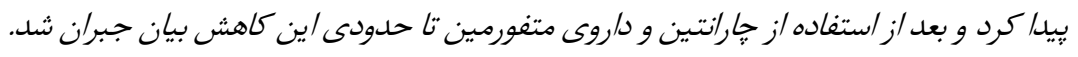

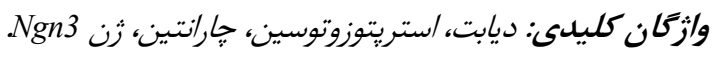

ديابت نوع يك و ديابت نوع دو تقسيم كرد. ديابـت نـوع يـك يـا مقدمه

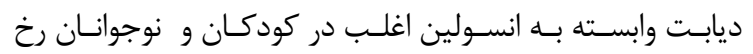

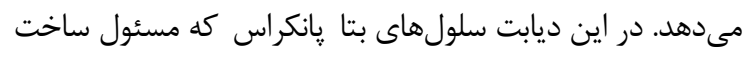

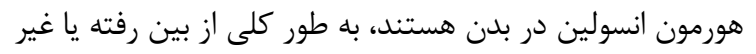

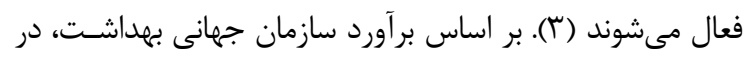

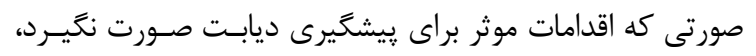

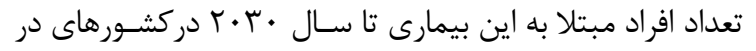

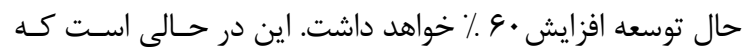

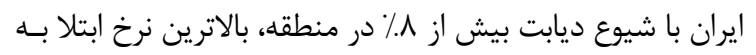

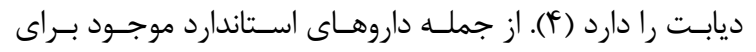

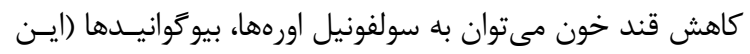

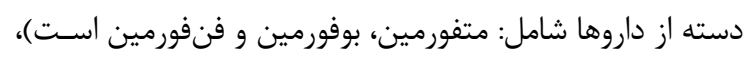

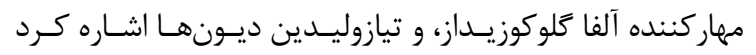

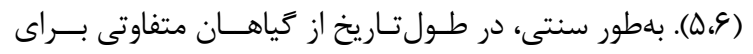

ديابت شايع ترين بيمارى مزمن متابوليك است، كـه بــهـ صـورت

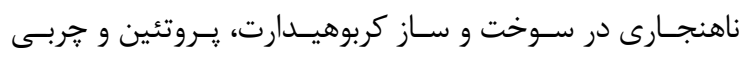

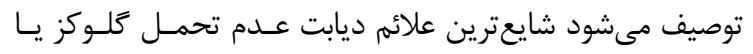

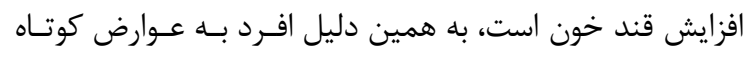

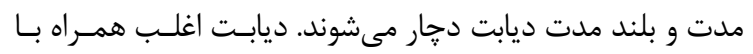

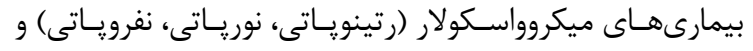

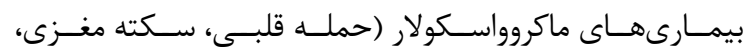

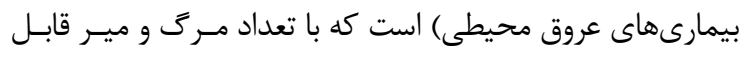

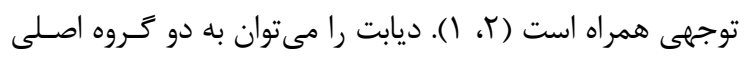

آدرس نويسنده مسئول: شهر كرد، دانشخاه آزاد اسلامى، گروه زيستشناسى، حسين ساز كار (email: hoseinsazgar@yahoo.com) ORCID ID: 0000-0001-9769-8932 تاريخ دريافت مقاله: : ت تاريخ بذيرش مقاله: TV/9/IT 
نقش آن طى تحقيقات متعـدد اثبـات شـده اسـت. Ngn3 يـكـ

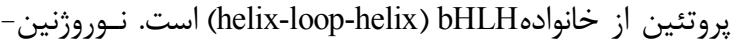

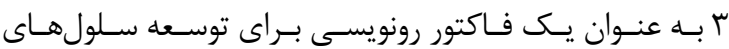

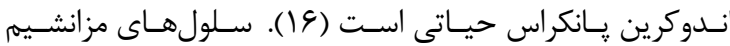
يانكراس زمان تمايز سلولهاى اندوكرينى را كنترل مـى كننـد و

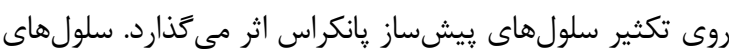

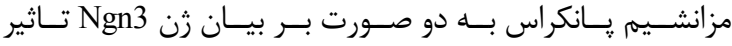
مى گذارند: ا - از طريق فاكتورهـاى ترشـحى باعـث مهـار تمـايز

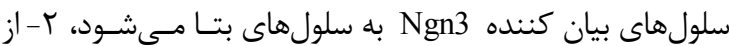
طريق تماس سلول با سلول باعث تاخير در بيان Ngn3 مىشود.

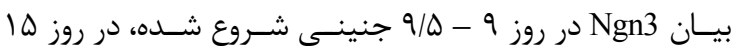
زمانى كه موج بزرى ايجاد سلولهاى غدد درون ريز وجـود دارد، به بيشترين مقـدار خـود مسىرسـد. بيـان Ngn3 يـك شـاخص عملكردى جمعيتهاى ييش ساز سلولهـاى جزايـر لانغرهـانس

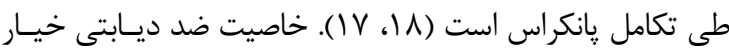
تلخ در مطالعات كذشته اثبات شـده اسـت. در ايـن مطالعـه بــه

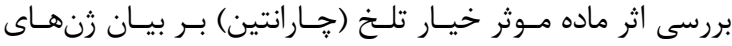

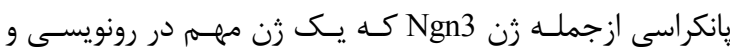

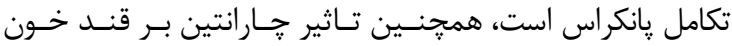
رتهاى ديابتى شده با استريتوزوتوسين يرداختيم.

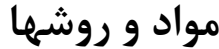 \\ تهيه رتها}

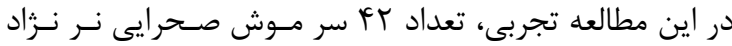

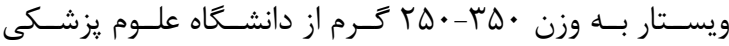
شهر كرد خريدارى گرديد و به اتاق حيوانـات واقـع در دانشـعاه

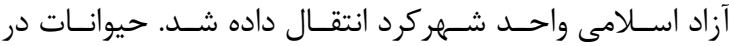
قفسهاى مخصوص خود نكَهدارى شدند و آب و غــذا بـهـ انـدازه كافى در اختيارشان قرار داده شد.

\section{كروه بندى رتها}

رتها در V ₹روه \& تايى به صورت تصادفى دستهبنـدى و در قفس هاى مجزا نكَهدارى شدند. آب و غذا براى همه يكسـان كروه A (سالم شاهد): شامل شـش سـر رت سـالـم بـود كــه روزانه فقط آب معمولى و غذاى استاندارد دريافت مى كردند.

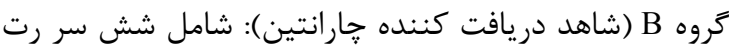
سالم بود كه روزانه آب معمولى و غـذاى اسـتاندارد و هرســهـ روز يك بار، طلى سى روز هر نوبت • ها ميلى جارانتين به صورت كاواز دريافت مى كردند.
كاهش قند خون و بهبود اثرات ديابت، استفاده شده و درطــــب سنتى ايـران و سـاير كثـورهاى جهـــان، اطلاعــات مفصلى در

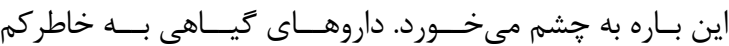
بودن اثرات جانبى، در دسترس بودن، هزينه نسـبتا كسم و مـوثر بودنشان، به طور وسيع در سرتاسر جهان تجـويز مـىشـوند (V).

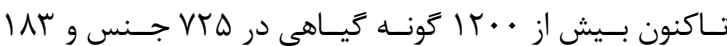

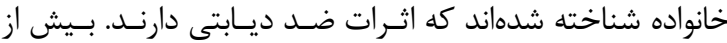

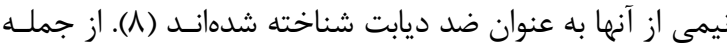

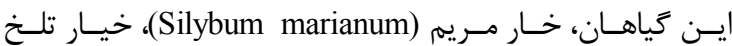

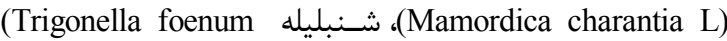
و (Vaccinium Arctostaphylos L) سـياه گيلـه graecum L) هندوانه ابوجهل (Citrullus colocynthis) ) هستند (9).

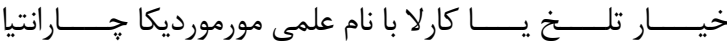

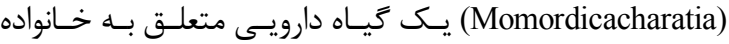

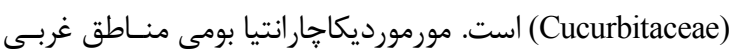
هندوسـتان، جــين و آسـيا اسـت. ايسـن گيــاه داراى مومورديوم جــارانتين، آسكوربيك اسيد، كليكوزيد و آلكالوئيد اسـت. ميوه و برگ زياه كارلا در طب سنتى هندوستان براى درمان يرقان و بيمارى ديابت كاربرد داشته اســت ( • (). دريثوهشهاى بيشين

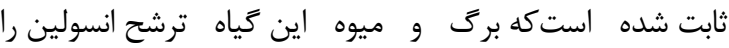

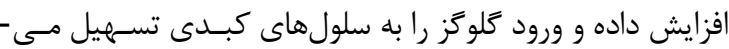

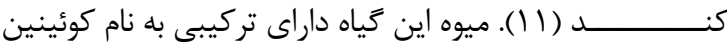
است و از اين رو مزهاى تلخ دارد. در ميوه اين كَياه (Charantin)

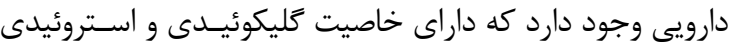
اســـــ ميوه نارس گياه فلاونوئيد و تركيبات فنولى بالايى دارد. در ميوه رسيده ميزان فلاونوئيد كمتر از ميوه نارس است. اين

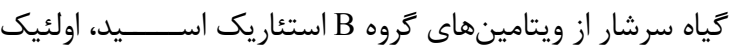
اسيد و اسيدهاى جرب است كـهـ بــراى درمـان ديابـت مفيدنــد

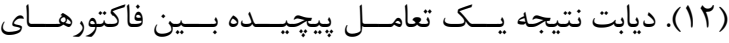

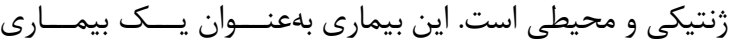

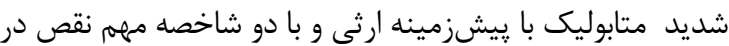

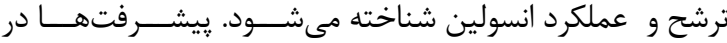

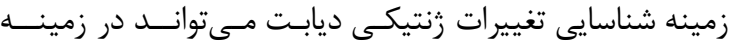

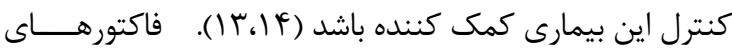
متفاوتى برتمايز سلولهاى بتـا درلوزالمعـده اثـر مسى گذارنـد؛ از

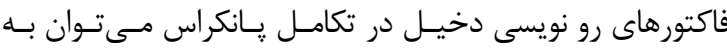
،Pax1 Neuron/Beta2 ،Notch signaling ،Neurogenin3 ‘HLxb9 ،Mist1 ،MafB ،MafA ‘Nkx6.1 ‘Nkx2.2 ‘Pax6 و Isi1

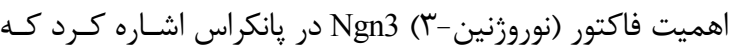


كردن رتها با استفاده از كلروفرم رتهــا بيهـوش شـدند. بـاــا.

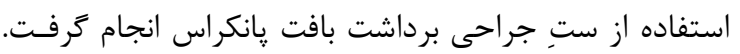

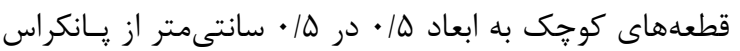

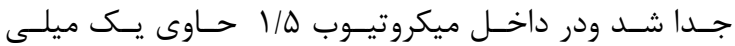
ليترRNA later قرار داده شد، به صورتى كه بافـت كـاملا در غرق شد و سيس ميكروتيوب و محتوياتش ابتـدا به مدت Fr ساعت در فريزر • •- درجه سانتى شدند و در نهايت به فريزر • V- درجه سانتى گراد منتقل شد

\section{RNA استخراج}

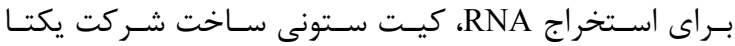

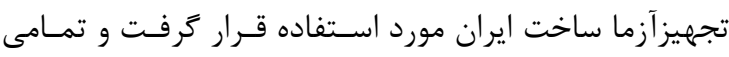

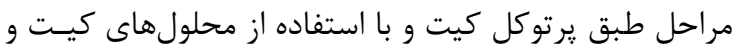

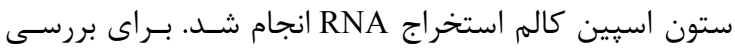

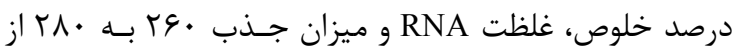
دستخاه اسيكتوفتومتر (Nano Drop) استفاده شد (YT)

ساخت

يس از اطمينان از خالص بودن RNA اسـتخراج شـده ســتـز cDNA انجام شد و تمامى مراحـل طبـق دسـتور العمـل كيـت و بــا استفاده از مواد و محلولهاى موجود در كيت در زيـر هـود و روى يخ انجام گرفت.

طراحى و سنتز يرايمرها

يرايمرهاى استفاده شده در اين يـرّوهش بـر اسـاس تـوالى زن

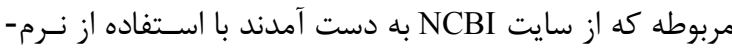

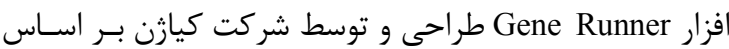

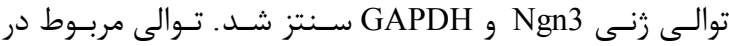
جدولهاى ا و r آورده شده است.

\section{Real Time RT-PCR مراحل انجام}

بـراى انجـام واكــش Real Time RT- PCR از كيـت SYBR ساخت شـركت يكتـا تجهيـز آزمــا اسـتفاده شــــ تمــام green مراحل در شرايط استاندارد و طبق يروتوكل كيت انجام گرفت.

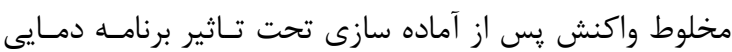

كروه C (كنترل منفى (شاهد ديابتى)): شامل شـش سـر رت

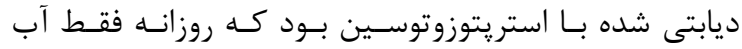
معمولى و غذاى استاندارد دريافت مى كردند. گروه D: شامل شش سر رت ديابتى شده با استريتوزوتوسين

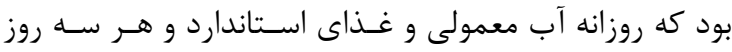

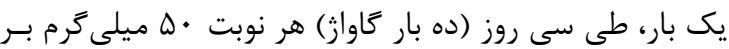
كيلوگرم متفورمين (داروى كاهنده قند خون) به صورت كاواز (خوراكى) دريافت مى كردند.

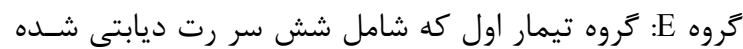
بــا استريتوزوتوسـين بـود كـهـه روزانـهـ آب معمــولى و غــذاى استاندارد و هرسه روز يك بار، طى سى روز (ده بار كاواز) هر

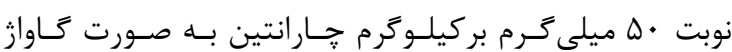
(خوراكى) دريافت مى كردند. Fروه F: Fروه تيمار دوم كه شامل شش سر رت رت ديابتى شـده

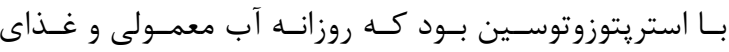
استاندارد و هر سه روز يكى بار، طى سـى روز (ده بـار گَاواز)

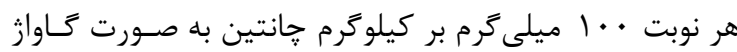
(خوراكى) دريافت مى كردند. زروه G: گروه تيمار سوم كه شامل شش سر رت ديابتى شده

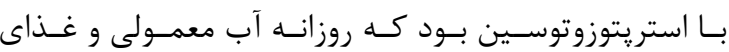
استاندارد و هر سه روز يك بار، طى سى روز (ده بار گاواز) هر

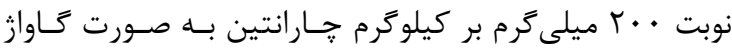

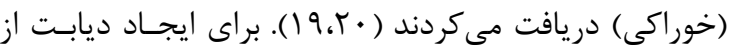

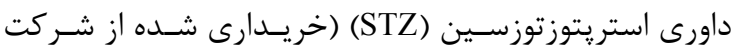

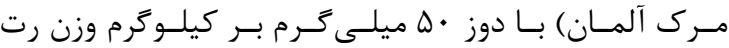
استفاده شد. مقدار استر يتوزوتوسين مورد نياز براى هر موش

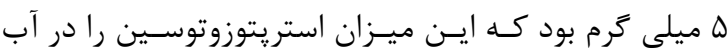

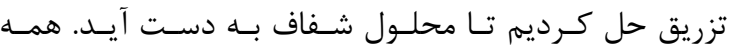
موشها، به جز زروه شاهد و كنتــرل جــارانتين، ايـن مقـدار

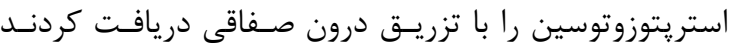

\section{نمونه كيرى از رتها} يس از سـى روز نعَـهـ دارى و انجــام دادن تزريـقهــا و حَـاواز

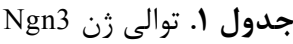

\begin{tabular}{rrr}
\hline Ngn3F & 5'-CAC CGC TGC TTG ACT CTG ACC-3' & Tm:62 \\
\hline Ngn3R & 5'-CAC TCC CCT CTT CTA CCC TTT G-3' & Tm:62 \\
\hline
\end{tabular}

جدول r. Tوالى زن G2 


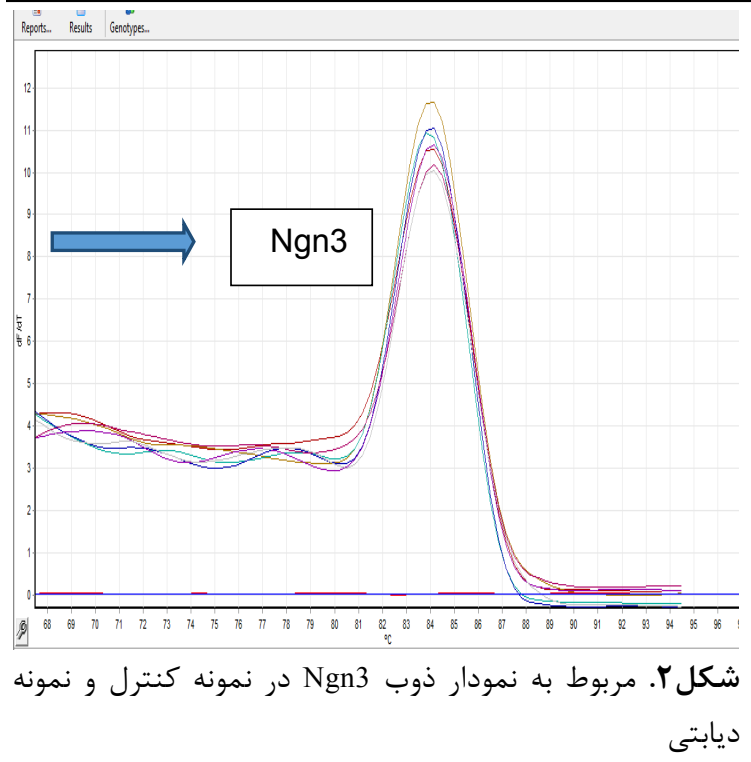

Real time RT-PCR منحنى تكثير

يس از انجام RT-PCR، منحنى تكثير CDNA براى GAPDH رسم شد و Ct هر كدام تعيين كرديد. منحنى تكنير

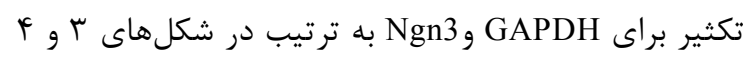

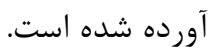

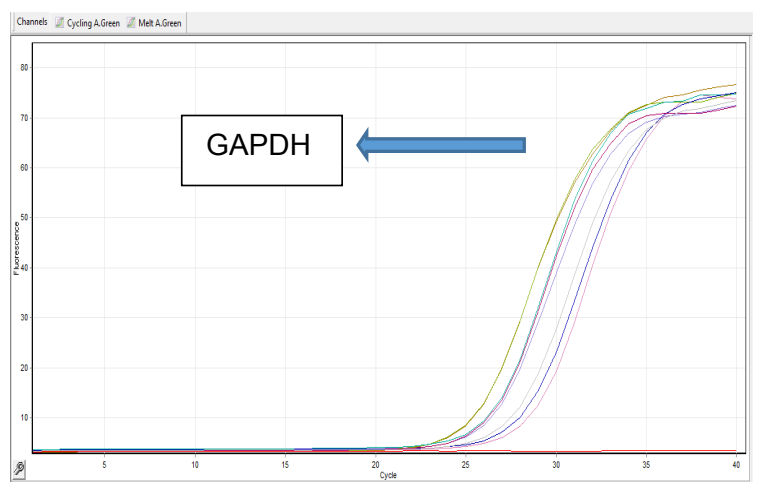

شكل r. مربوط به منحنى تكثير GAPDH در نمونه كنترل و

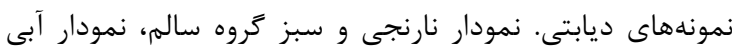

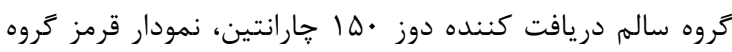

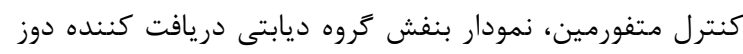

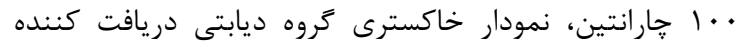

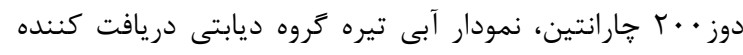

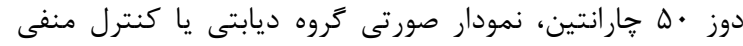

تحليل آمارى زن Ngn3 با استفاده از نرمفزار انجام شد و از آنجايى كه دادهها نرمال بود از آنمون آنادئ آناليز

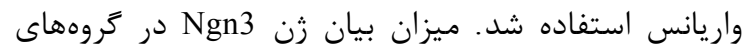

ذكر شده در يروتوكل كيت در دستخاه Real Time قرار گرفت.

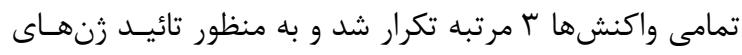

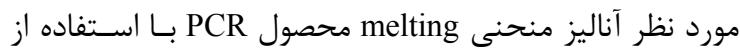

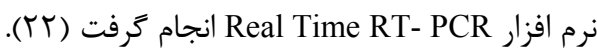

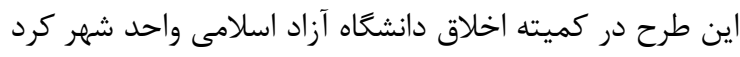

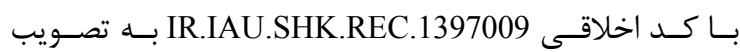

$$
\text { رآناليز آمارى }
$$

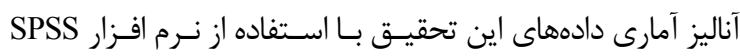

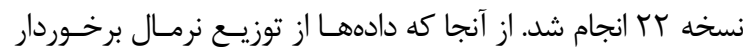

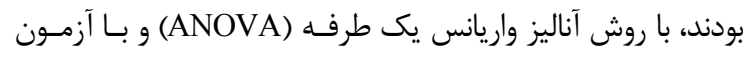

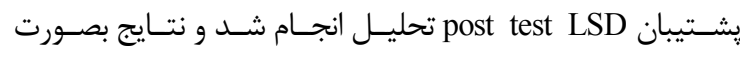

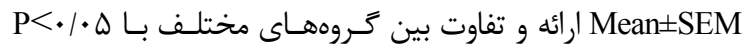

$$
\text { معنى دار تلقى شد. }
$$

يافته ها

\section{Rنحنى هاى ذوب Real time RT-PCR}

در اين منحنى شدت فلورسنت در برابر دماى ذوب DNA

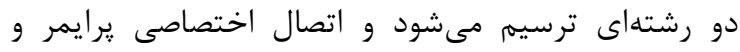

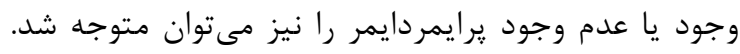

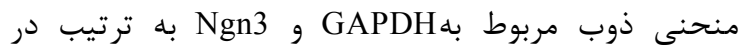

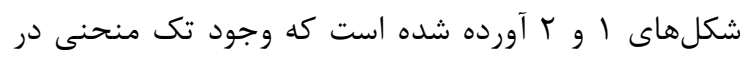

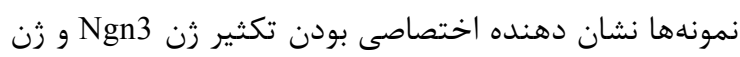
GAPDH

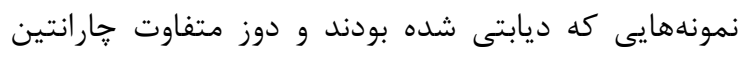

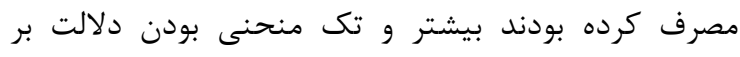

$$
\text { اختصاصى بودن تكثير زن Ngn3 است. }
$$

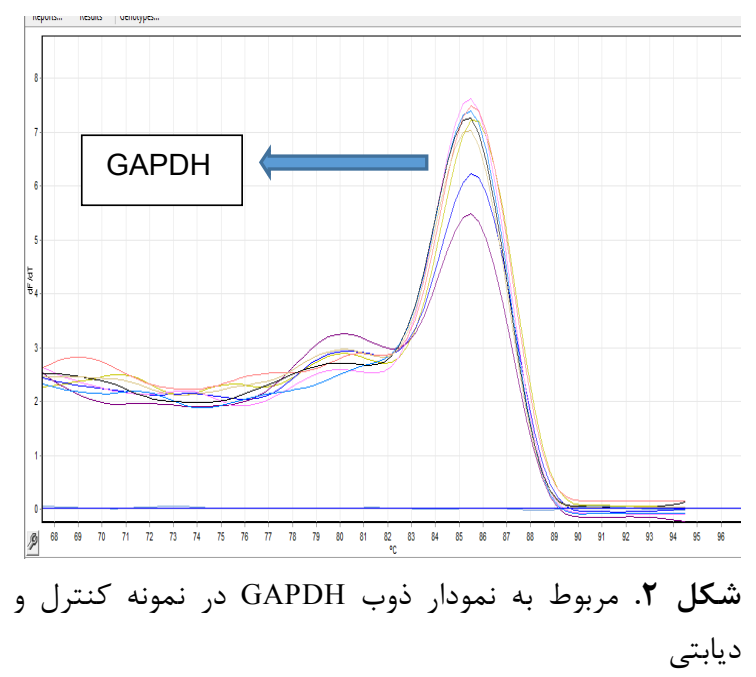




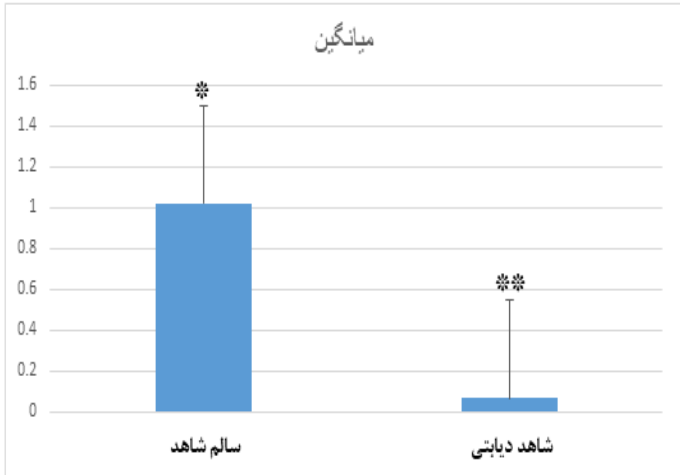

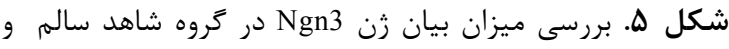

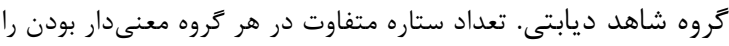

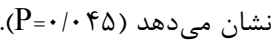

ميزان بيان اين زن در گروه سالم دريافتكننده دوز

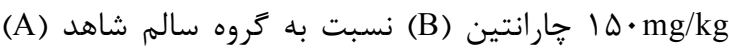
تا حدودى افزايش بيان داشت، ولى اين افزايش بسيار

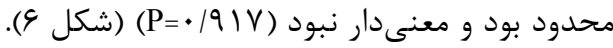

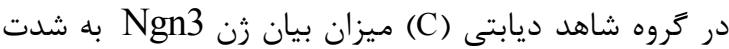

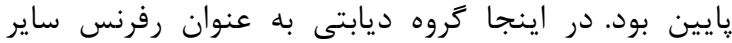

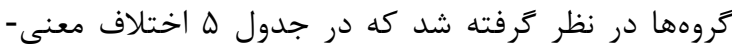
دارى ساير گروههاى مورد مطالعه با اين گروه، نشان داده شده است. ميزان بيان زن به صورت ستونى نيز در شكل Vإي زير آورده شده است.

\begin{tabular}{|c|c|}
\hline ميانخين ـانحراف معيار & كروه \\
\hline$\| \cdot r I V \pm \cdot / r \cdot 9 F$ a & شاهد ديابتى C \\
\hline$\Lambda / r \cdot \uparrow \Lambda \pm \cdot / r G q \uparrow$ bc & D D Dيافت كننده متفورمين \\
\hline$G / V F G V \pm \cdot|\Delta| r F b$ & دريافت كننده دوز ·له جارانتين E \\
\hline $\mid r / q T \cdot \Delta \pm I / V A r \Delta c$ & 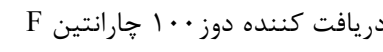 \\
\hline $9 / \wedge \Delta \cdot 1 \pm \cdot / / r 4 \Delta$ bc & 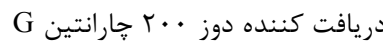 \\
\hline
\end{tabular}

كمترين ميزان بيان مربوط به كروه ديابتى (C) بود.

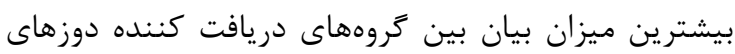

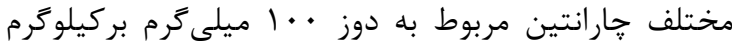

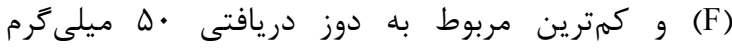

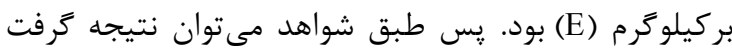
افزايش بيان زن وابسته به دوز نبوده است. يس از إيجاد ديابت دركروهاى بيمار به شدت افت پِيدا كرده و بعد از
شاهد سالم (A) و شاهد ديابتى (C) در جدول ب آورده شده

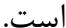

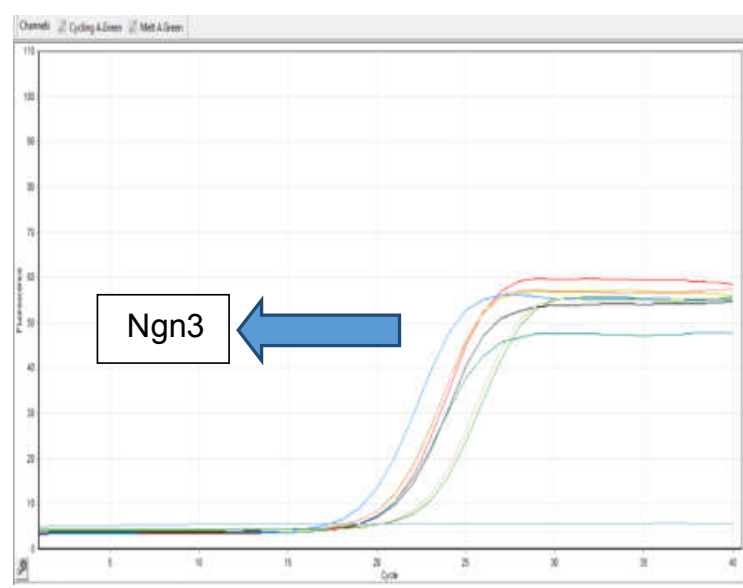

شكل F. مربوط به منحنى تكثير Ngn3 در نمونه كنترل و

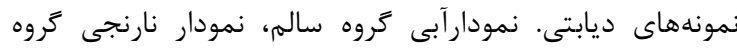

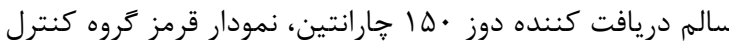

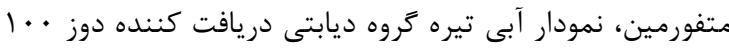

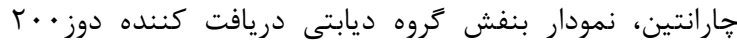

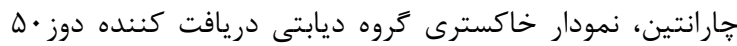

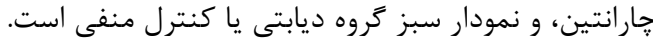

بررسى ميزان بيان زن Ngn3 در گروه شاهد سالم و گروه شاهد ديابتى به عنوان كنترل منفى نشان دان داد ميزان بئن بيان اين زن در رتهاى ديابتى نسبت به رتهاى ساله سالم به صورت

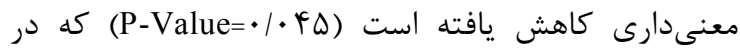
شكل ها آورده شده است. ميزان بيان زن Ngn3 در گروه شاهد سالم (A) و كروه سالم الم

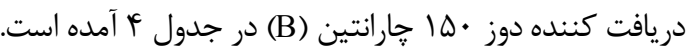
جدول بـ. ميزان بيان زن Ngn3 در كروههاى شاهد سالم (A) و شاهد ديابتى (C)

\begin{tabular}{|c|c|}
\hline انحر اف معيار 土 ميانكَين & كروه \\
\hline W.rIV $\pm \cdot /$ ragr a & سالم شاهدA \\
\hline $.1 .9 v \cdot \pm .1 .19 q^{b}$ & شاهد ديابتى \\
\hline
\end{tabular}
جدول F. ميزان بيان زن Ngn3 در كروه شاهد سالم (A) و كروه

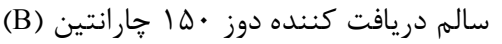

\begin{tabular}{|c|c|}
\hline انحراف معيار 土 ميانكَين & كروه \\
\hline $1 / \cdot r / 9 \pm \cdot / r 99 r^{a}$ & A سالم شاهد A \\
\hline $1 / \cdot \varphi q \Lambda \pm \cdot / \cdot \Delta \varphi \varphi^{a}$ & سالم دريافت كننده حارانتين B \\
\hline
\end{tabular}


و نياز به ساخت تركيبى كياهى كه علاوه بر عوارض جانبى

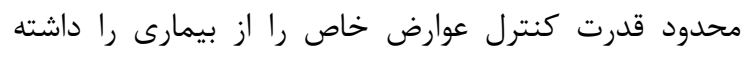

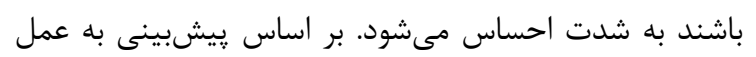

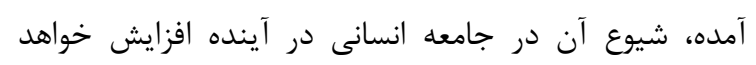

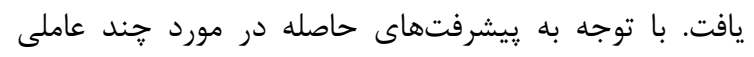

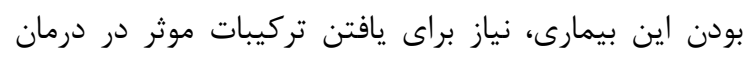

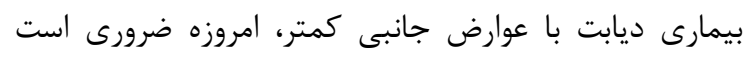

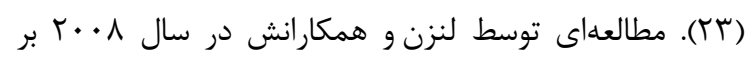

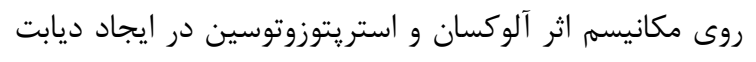

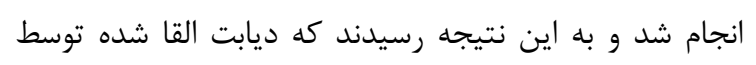

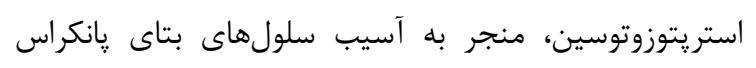

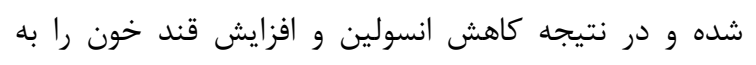
دنبال دارد (YY). در مطالعهاى كه راتدو همكارانش در در سال

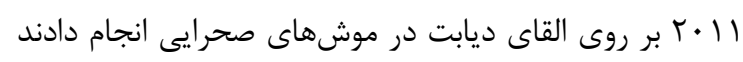

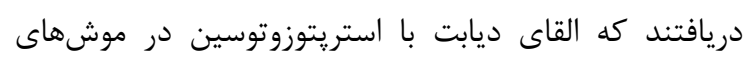

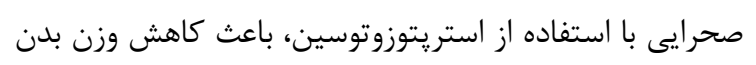

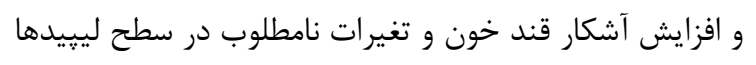

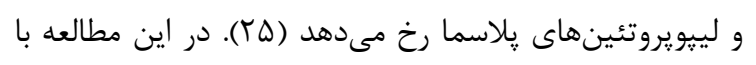

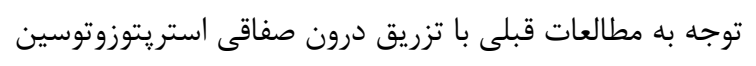

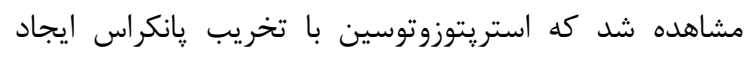

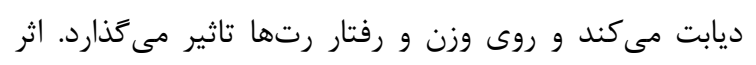

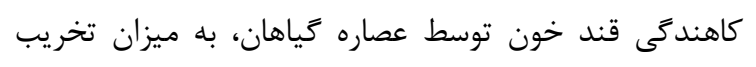

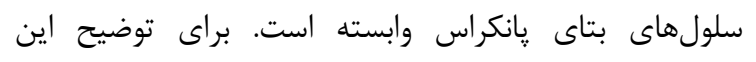

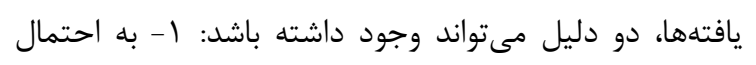

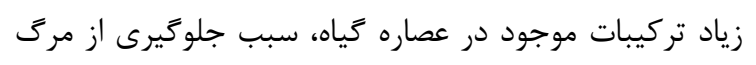

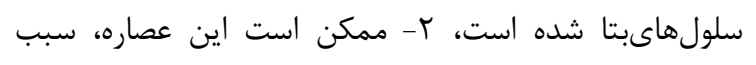

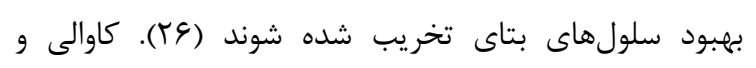

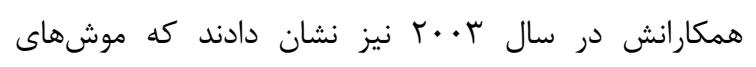

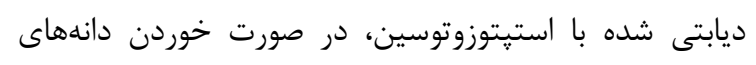

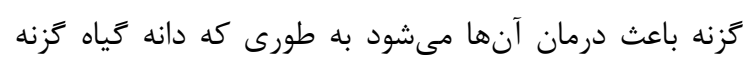

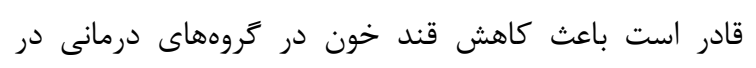

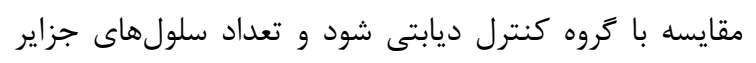

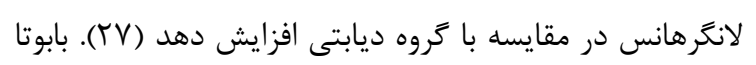

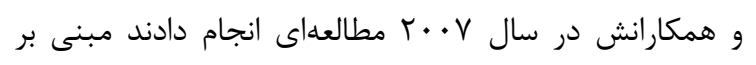

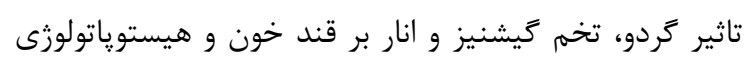
يانكراس موش صحرايى كه با آلوكسان ديابتى شده بودئ بودند

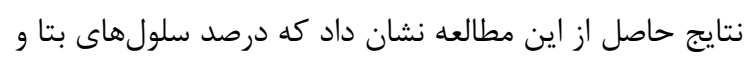

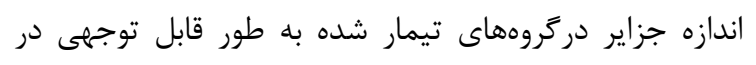

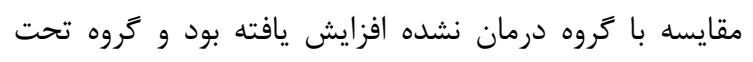

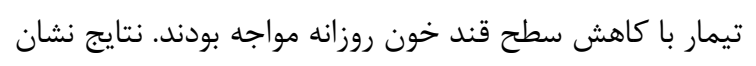

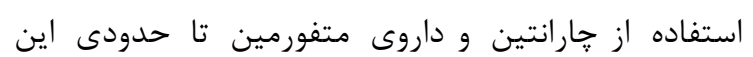
كاهش بيان جبران شده است.

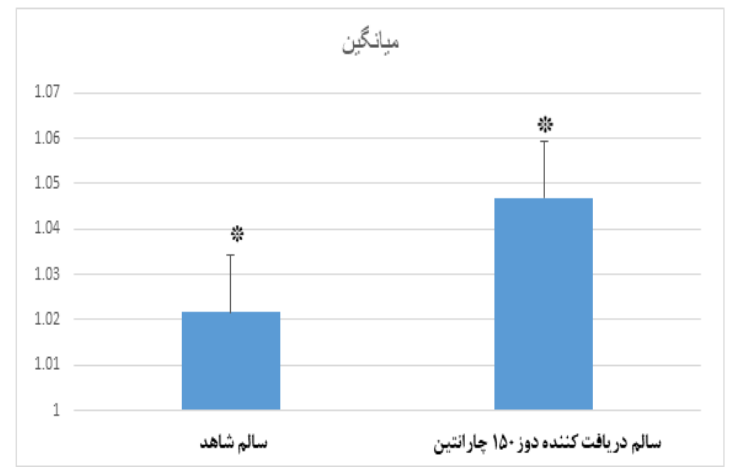

شكل צ. ميزان بيان زن Ngn3 در كروه سالم دريافت كننده دوز

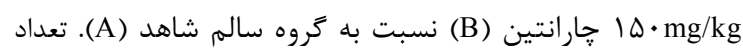

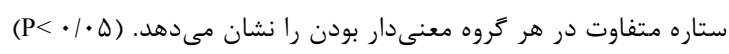

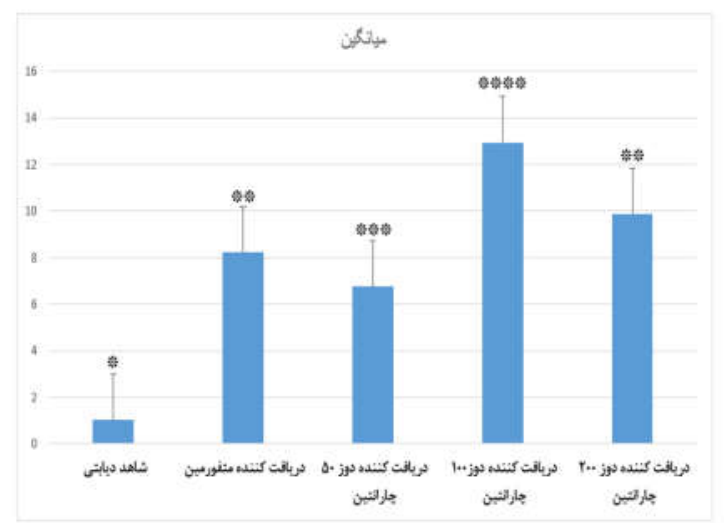

شكل V. ميزان بيان زن Ngn3 در تروههاى مختلف. تعداد ستاره

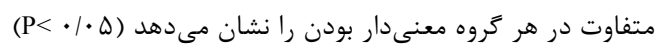

\section{بحث}

ديابت بيمارى شايعى در عصر حاضر است كه مىتواند حاصل

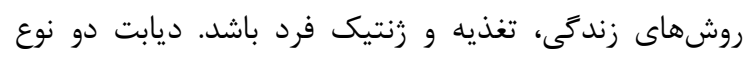

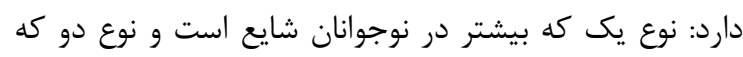

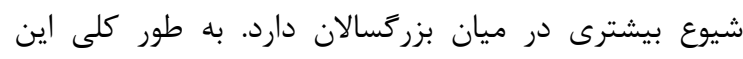

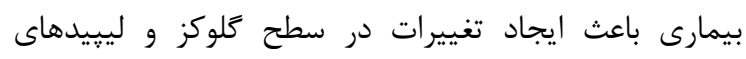

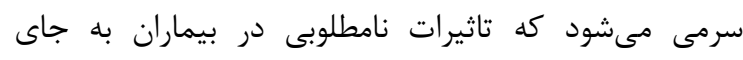

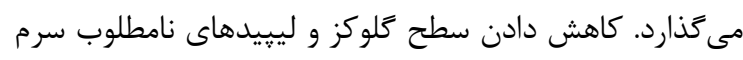

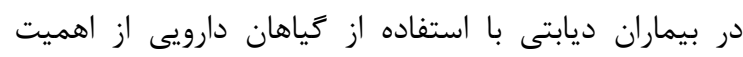

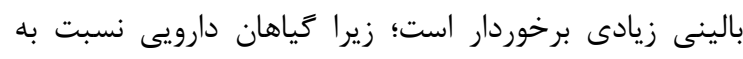

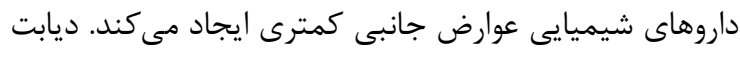

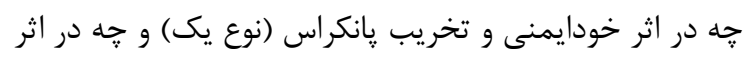
اختلال در جذب و ترشح انسولين (نوع دو) ايجاد شود، زمينه

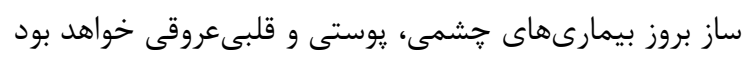




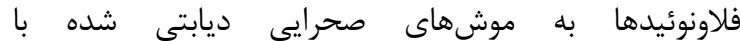
استريتوزوتوسين، موجب كاهش (وابسته به دوز فلاونوئيد تزريقى) كلوكز مىشود، درحالى كه اثر محسوسى بر غلظت موجت

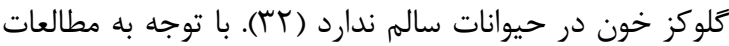
كذشته و شباهت مطالعه انجام شده مىتوان دريافت كه اين مطالعه با مطالعه قاسمى، روستاليس، كاشيك، حسين فلاح

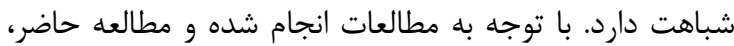
استريتوزوتوسين باعث القاى ديابت در موشها و تخريب يانكراس، افزايش مقدار قند خون و كاهش وزن بدون بدن موشهابـ مىشود و همان ₹ونه گياهان دارويى در درمان ديابت تاكنون تاثير به سزايى داشتهاند و عوارض جانبى كمترى نسبت به داروهاى شيميايى موجود دارند در اين مطالعه انتظار مىرود كه جارنتين باعث كاهش قند خون و باز سازى پانكراس تخريب شده توسط استريتوزوتوسين شود.

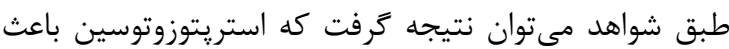
تخريب يانكراس، كاهش وزن بدن و افزايش قند خون رتها مىشود. به علاوه، با بررسى دوزهاى مختلف جارانتين به

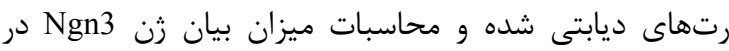
رتها مىتوان نتيجه گرفت كه افزايش بيان زن وابسته به دوز جارانتين نيست. زيرا يس از ايجاد ديابت درگروهاى بيمار بيان

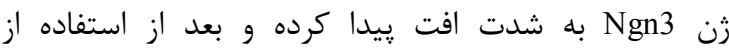
جارانتين در زروههاى مختلف و داروى متفورمين در زروه كنترل تا حدودى اين كاهش بيان جبران شده است.

\section{قدردانى و تشكر}

اين مقاله استخراج شده از يايان نامه كارشناسى ارشد است. بدين وسيله از اساتيد محترم و مسئولين آزمايشگاه دانشگاه آزاد اسلامى واحد شهركرد به منظور فراهم نمودن امكان انجام

$$
\text { اين تحقيق سياس ززارى مىشود. }
$$

داد احتمالا اين تركيب مىتواند به كاهش عوارض هيستوياتولوزى ديابت نوع دو كمك كند (Y^). كاشيك و همكارانش با مرورى بر مطالعات در سال ها • ب تحت عنوان "كو كوربيتاسين: نخاهى عميق به كاربرد مولكول هاى هدايتخر استخراج شده از طبيعت در داروسازى" بيان داشتند كه به به كوكوربيتاسين از لحاظ ساختارى از يتانسل دارويى فراوانى

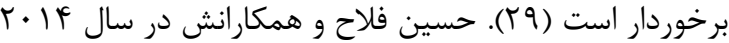
با مطالعهاى در خصوص اثرات ضد ديابتى عصاره مومورديكا جارانتيا، خرگوشهاى ديابتى ناشى از آلوكسان با عصاره متانولى و اتانولى مومورديكا جارانتيا مورد درمان قرار گرفتند و كاهش مب درصدى هيير كليسمى توسط عصاره اتانول مشاهده

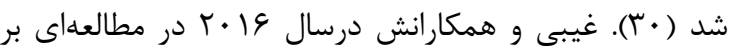
موشها دريافتند كه رزيم يرجرب - STZ مدل مناسب و

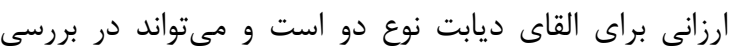

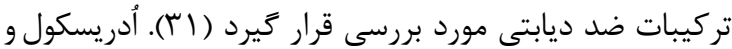
همكارانش درسال ها • ب با تحقيق بر روى بيان فاكتورهاى انسولين ساز انسانى دريافتند كه فاكتور Ngn3 بخش طبيعى

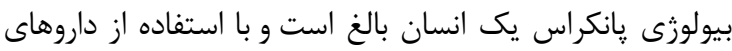
اختصاصى مى توان تعداد آنها را افزايش داد و با تبديل آنها به سلولهاى تمايز يافته غدد درون ريز لوزالعمده، سلولهاى بتاى كارآمدى را توليد كرد كه براى درمان ديابت به كار

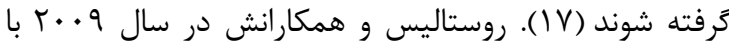
تحقيق بر روى نوروزنين به عنوان يك تنظيم كننده اصلى تمايز و باز سازى جزاير يانكراس دريافتند كه Ngn3 به به به عنوان يك تنظيم كننده اصلى توسعه غدد درون ريز پانكراس و توجه به يافتن روشهاى درمانى براى افزايش بيان Ngn3 در ديابت

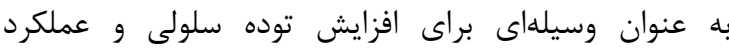

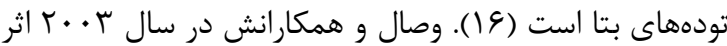
آنتىديابتيك استريتوزوتوسين بر روى موشهاى صحرايى را

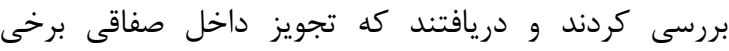

\section{REFERENCES}

1. Meusel, L, Kansal, N, Tchistiakova, E, Yuen W, MacIntosh, B, Greenwood, C, et al. A systematic review of type 2 diabetes mellitus and hypertension in imaging studies of cognitive aging: time to establish new norms. Front Aging Neurosci 2014.6: 148

2. Patel DK, Kumar R, Prasad SK, Sairam K, Hemalatha S. Antidiabetic and in vitro antioxidant potential of Hybanthus enneaspermus (Linn) F. Muell in streptozotocin-induced diabetic rats. Asian Pac J Trop Biomed 2011;1: 316-322.

3. Scherbaum WA. Insulin therapy in Europe-Diabetes. Metab Res Rev 2002; 3: 3:S50-6.

4. Shaw JE, Sicree RA, Zimmet PZ. Global estimates of the prevalence of diabetes for 2010 and 2030. Diabetes Res Clin Pract 2010;87:4-14.

5.Nolte MS, Karam JH, ed. Pancreatic hormones and antidiabetic drugs. Basic and clinical pharmacology. $9^{\text {th }}$ ed. New York: McGraw Hill Companies; 2004. P.708. 
6. Hald A, Lotharius J. Oxidative stress and inflammation in Parkinson's disease: is there a causal link? Exp Neurol 2005;193:279-90.

7. Venkatesh S, Reddy GD, Reddy BM, Ramesh M, Rao AV. Antihyperglycemic activity of Caralluma attenuata. Fitoterapia 2003; 74:274-9.

8. McCune LM, Johns T. Antioxidant activity in medicinal plants associated with the symptoms of diabetes mellitus used by the indigenous peoples of the North American boreal forest. J Ethnopharmacol 2002;82:197-205.

9. Fallah Huseini H, Fakhrzadeh H, Larijani B, Shikh Samani A. Review of anti-diabetic medicinal plant used in traditional medicine. J Med Plants 2006; 1 :1-8 [In Persian]

10. Hajinejad MR, Salehi Moghadam M, Hajian Shahri S, Vaezi E, Jamshidian A, Sa'atati D. Effect of Carla leaf extract on serum glucose, lipid and malondialdehyde levels in streptozocin-induced diabetic rats. Diabetes Nur 2014;2:8-19. [In Persian]

11. Ahmed I, Adeghate E, Cummings E, Sharma AK, Singh J. Beneficial effects and mechanism of action of Momordica charantia juice in the treatment of streptozotocin-induced diabetes mellitus in rat. Mol Cell Biochem 2004;261:63-70.

12. Yibchok-anun S, Adisakwattana S, Yao CY, Sangvanich P, oengsumran S, Hsu WH. Slow acting protein extract from fruit pulp of Momordica charantia with insulin secretagogue and insulinomimetic activities. Biol Pharm Bull 2006;29:1126-31.

13. Huang QY, Cheng MR, Ji SL. Linkage and association studies of the susceptibility genes for type 2 diabetes. Yi Chuan Xue Bao 2006; 33:573-89.

14. Patlak M. New weapons to combat at ancient disease: treating diabetes. FASEB J. 2002:16:1853.

15. Qiu Li, Zhi-Chun Lai. Recent progress in studies of factors that elicit pancreatic $\beta$-cell expansion. Protein Cell 2015; 6: 81-87.

16. Rukstalis JM, Habener JF. Neurogenin3: a master regulator of pancreatic islet differentiation and regeneration. Islets 2009;1:177-184.

17. Gomez DL, O'Driscoll M, Sheets TP, Hruban RH, Oberholzer J, McGarrigle JJ, et al. Neurogenin 3 expressing cells in the human exocrine pancreas have the capacity for endocrine cell fate. PLoS One 2015;10:e133862. doi:10.1371/journal.pone.0133862.

18. Pagliuca FW, Melton DA. Melton. How to make a functional $\beta$-cell. Development 2013;140:2472-83.

19. Khaleghi S, Bahrami G, Mahmoodi M, Asgari V, Mostafaie A. Hypoglycemic Effect of Hydroalcoholic Extract and Hexane Fraction of Persian Shallot (Allium Hirtifolium Boiss) Extract in Streptozotocin-Induced Diabetic Rats. JRPS. 2015; 5: 33-40.

20. Kermany H, Shahanipour K, Nakhaee AR. Effect of aqueous and methanolic extracts of Momordica charantia fruit on blood glucose and liver enzymes in diabetic rats. Quarterly of the Horizon of Medical Sciences 2015; 21:105-112. [In Persian]

21. Abdollahi M, Zuki ABZ, Goh YM, Rezaeizadeh A, Noordin MM. The effects of Momordica charantia on the liver in streptozotocin-induced diabetes in neonatal rats. Afr J Biotechnol 2011;26:13-21.

22. Ahangaran, A, Mosahebi Mohammadi G, Koohi Habibi M, Khezri S, Shahraeen, N. Use of rapid serological and nucleic acid-based methods for detecting the soybean mosaic virus. J Agric Sci Technol 2009.11: 91-97.

23. Al-said MS, Abdelsattar EA, Khalifa SI, EI- Feraly FS. Isolation and identification of an anti- inflammatory principle from Capparis spinosa. Pharmazie 1988; 43: 640-41.

24. Lenzen S. The mechanisms of alloxan and STZ- induced diabetes. Diabetologia 2008;51:216-226.

25. Rethod NR. Chime HR. Hypoglycemic effect of calotropis gigantean linn.Leaves and flowers in STZ-diabetic rats. J Oman Med 2011; 26:104-108.

26. Ardestani A, Yazdanparast R, Jamshidi Sh. Therapeutic effects of Teucrium polium extract on oxidative stress in pancreas of streptozotocin-induced diabetic rats. Med Food 2008; 11: 525-32.

27. Kavalali G. Tuncel H. Hatmi HH. Hypoglycemic activity of Urtica pilulifera in pilulifera in STZ-diabetic rats. J Ethnopharmacol 2003;84:241-245.

28. Baboota, S. Kohli, K. Ahmad, S. Ali, J. Silymarin: a review of Pharmalogical aspects and bioavilability enhancement approaches. Indian J Pharamacol 2007; 39:172-179. 
29. Kaushik U, Aeri V, Mir SR. Cucurbitacins - An insight into medicinal leads from nature. Pharmacogn Rev $2015 ; 9: 12-8$

30. Hussain F, Tahira S. Antidiabetic evaluation of Momordica charantia L fruit extracts. West Indian Med J 2014; 63:294-99.

31. Gheibi S, Bakhtiarzadeh F, Ghasemi A. A review of high fat diet-streptozotocin model for induction of type 2 diabetes in rat. Iranian Journal of Endocrinology and Metabolism 2016; 18:135-148. [In Persian] 